\title{
Tri sondy z minulosti do prítomnosti
}

\author{
Viera Žemberová (Prešov)
}

Oles Uljanenko: Tady na Jihu. (Tam, de Pivdeň. Treandt, 2009). Překlad Jiřina Dvořáková. Větrné mlýny, 2015. 140 s. ISBN 978-80-7443-171-5.

Sergej Lebeděv: Děti srpna. (Ĺjudi avgusta). Přeložil Libor Dvořák. Přibram: Pistorius\&Olšanská, 2016. 280 s. ISBN 978-80-87855-43-0.

Michail Ševeljov: Nejsem Rus. (Ne russkij). Přeložil Jakub Šedivý. Praha: Prostor, 2016. 173 s. ISBN 978-807260-333-6.

Zo slovanských literatúr, ktoré sa v prozaickej tvorbe látkou navracajú do nedávnej národnej a spoločenskej minulosti svojej krajiny sa presadzuje tematický záujem predovšetkým novej aj debutujúcej spisovatel'skej generácie, ktorá chce poznat súvislosti, porozumiet, dozvediet sa, dopovedat, ale zvlášt vlastnými literárnymi výpoved’ami odpovedat konečne na otázky, ktoré spájajú rod, rodinu, blízkych a krajinu s dramatickými aj tragickými udalostami minulého storočia. Autori na literárnej výprave za pre ne nezastupitel'nými výpravami za pravdou a za odpoved’ami tam, kde sú pramene k nej, si vyberajú také témy, ktoré sa odvíjajú na počiatku ako privátne a postupne morálne zatažujú rolu protagonistu, pritom reagujú rozlične na zovšeobecnené historické a praktikované etické zmeny v spoločenskom živote od konca minulého storočia vo svojom národnom spoločenstve a pri nazeraní na spoločné dejiny. Odlišnost’ autorského postoja, výberu látky a tematiky sa spája takmer vždy s prežívajúcou traumatizujúcou rodinnou situáciou, s návratom v čase $\mathrm{k}$ uchovanej pamäti starých aj svojich rodičov. Odraziskom sa osobný a v horizontále spoločenského života, na jeho mocensky zovšeobecnené príkazy, ukrývané zločinné tajomstvá a praktiky na mocenské ovládanie súčasníkov sa pre prozaikov postupne zmenili na postup odvíjania zovšeobecneného až univerzálneho problému o deptajúcej moci (to tvorí dejinnú a spoločenskú látku), na prozaikmi obnažované príbehy z tajomstiev o krutej neúcte voči životu jednotlivca aj národného spo- ločenstva. Pre autorov Olesa Uljaneka, Sergeja Lebeděva a Michaila Šaveljova sa prozaickými príbehmi legalizuje (generačné) hl'adanie pravdy aj spravodlivosti pre tých, čo nesú vo svojich osudoch krivdy minulosti, aby literárnymi nástrojmi zverejnili poznanie, zovšeobecnili pravdu osvojenú si predovšetkým z osobných dejín pre nich blízkeho člena rodiny. Stratégia autorského zámeru sa zapojila do mravnej vôle spoločnosti poznat a vyrovnat sa aj literárnymi nástrojmi historickou aj mravnou pamätou s tým, čím prešli ich predkovia a ich krajina.

\section{Svět je takovej podfuk, až hrůza}

Cesty vyrozprávaných osudov o tragických osobných príbehoch jednotlivcov bez minulosti a budúcnosti, žijúcich na okraji vel'kých i malých miest spravidla prosperujúcej spoločnosti v getách narkomanov, zlodejov, mravne narušených asociálov, kam sa spravidla nie vždy iba svojím rozhodnutím dostali medzi rozvrátených vydedencov vyvolávajúcich vo svojom okolí iba strach, odmietnutie a zhnusenie, teda tí chlapci a dievčatá, ktorí sa od detských a chlapčenských rokov ocitli na dne a túžia na prahu svojej dospelosti nájst' v sebe odvahu aj pevnú vôlu raz, ked' nastane pre nich ten deň, sú príbehmi o tom, ako možno raz nasadnút do skutočného vlaku a navždy sa vzdialit z ničoty, brutality, nízkosti a neúcty tak k sebe, ako k d’alším zo svojho spoločenstva vydedencov. Život či živorenie ako rozdrobená a tragická prí- 
ležitost' je sprevádzaná nádejou na (vy)oslobodenie sa zo siete krutej a bezohladnej manipulácie, strachu, zločinu, závislostí, nenávisti a pomsty, ako zanechat' za sebou temnú osobnú minulost', našli svoje vyrozprávané literárne príbehy dávno a z pera aj skúseností mnohých rozprávačov, raz v strohých inokedy vo výrečných osudoch postáv ponorených do ničoty osudového, či iba telesného prežívania v takých krajinách, miestach a udalostiach, v ktorých sa vytrácajú základné civilizačné a humanistické poučenia o ludskosti až po príbehy tých, ktorých vyslobodila $\mathrm{z}$ dna osobná vôla, emócia a poznanie, že už nemožno hlbšie klesnút. Próza Olesa Uljanenka Tady na jihu (Jihu) sa látkou, tematikou, výberom postáv spomedzi mladistvých a mladých ludí, zvoleným typom autentického rozprávača a ústrednou tézou, že možno prekročit svoj predlžujúci sa tieň zániku, nezatažit sa zločinnými konfliktami a tézou $\mathrm{v}$ role pointy $\mathrm{z}$ existenciálneho nadhladu vypovedat ponad intímne a prežité nemilosrdne o tom, že detských aj pubertálnych (ne)literárnych príbehov a juhov aj Juhov zostáva v (ne)literárnom svete nad’alej príliš mnoho. Paradoxne nemusia tieto asociálne getá o sebe vediet', a predsa ich organizačná schéma aj vnútorné normy sa nelísia ani nemenia svojou spustnutostou, typmi násilných lokálnych vodcov, ale odlišiti ich môže pôvodný jazyk, no obsah a slang ich ,južnej“ reči na akomkolvek a kdekolvek jestvujúcom Juhu bude sa zdokonal'ovat’ z generácie na generáciu, vklad do zmien prinesie raný vek a rafinovaná skúsenost' jeho nových obyvatelov. Oles Uljanenko ${ }^{1} \mathrm{mal}$ mravné, estetické, kultúrne problémy pri uvádzaní svojich textov do ukrajinského literárneho života $^{2}$, ale realistické a existenciálne rozvinuté návraty do rodovej, rodinnej, osobnej pamäti nesprevádzajú len jeho prózu³. Literárne vyrovnávanie sa s pamätou dejinného rozmeru v ukra-

1 Ukrajinský spisovatel' Oles Uljanenko (1962-2010).

2 Na prebale českého vydania Tady na Jihu je informácia o „románovej tvorbe“: Stalinka, Znak Saboatha, Žena jeho snů. Do literárneho života vstúpil v devätdesiatych rokoch časopiseckou tvorbou. „Bèhem svého bouřlivého żivota obohatil Uljanenko ukrajinskou a světovou literaturu o více než dvacet prozaických titulü“.

3 Bližšie v práci CHLAŇOVÁ, Tereza a kol.: Putováni současnou ukrajinskou literárni krajinou. Prozaická tvorba jinskej literatúre novej autorskej generácie získava na naliehavej potrebe sebaidentifikácie a na formovaní postojov voči aktuálnemu, výraznejšie a väčšmi voči historickému spoločenskému vedomiu. Z literárnej estetiky a noeticky sa Uljanenkova autorská stratégia sústredila výlučne a iba vertikálne na kategóriu škaredé, z morálky stupňujúco rozvíja rafinovane utváranú a verbálne vyjadrenú kategóriu zlo, sociálne povedomie príbehu sa ukotvilo v kategórii nízke, asociálne, z rodového prístupu k postave a sujetu sa detailne prelieva prostredníctvom takmer náučne vyjadrených opisov, detailov, komentárov to, čo možno pochopit ako primitívne a prvosignálové medzi kontaktom ženskej a mužskej postavy. Juh, nech je kdekolvek vo vel'komeste, v malom meste či v inak lokalizovanom priestore sa uzavrie pri každej mužskej postave fyzicky alebo situačne príbehovými schémami, a tie sú účinné, podla tradície patria do zvyklostí správania sa v spoločenstve asociálov (od maloletých po mladých mužov a ženy). Uljanenkov príbeh voči esteticky a morálne nízkemu v látke a tematike kladie kompozíciu, narátora, sujet a variácie postáv prototypov možností, aké naznačuje žánrové podložia na ich vyrozprávanie, ale naznačované románové žánrové iniciácie tam chýbajú. Univerzálne naznačený priestor, lokalita, mesto, krajina, kontinent (juh/Juh) iniciujú v súbežných dejových líniách sociálnu, lúbostnú, dobrodružnú, kriminálnu prozaickú žánrovú formu, ktorá má rámcovanú kompozíciu objektívnym časom (rok 1979). Kategória priestoru a kategória času nevytvárajú napätie, vol’né presuny medzi nimi využíva rozprávač ako hru medzi svojou pubertálnou pamätou a ozvenami emotívnej intenzity toho, čo prežil. Napokon ambíciou narácie zostáva rozprávačova „potreba“ rekonštruovat svoju ranú mladost po vek nenaplnených osemnást rokov, ked' sa jeho životným, skúsenostným, citovým a sociálnym zázemím stane juh/Juh preplnený mužskými a ženskými prototypmi zo strateného života a jeho drakonických pravidiel, ale predovšetkým pozorovanie vzniku osobnej moci a uplatňovanie

představiteli tzv. "stanislavského fenoménu “. Červený Kostelec: Pavel Mervart, 2010. 
nepísaných zákonov zločinu: ,je rok 1979, za pár měsicu nastane rok osmdesát" (s. 136). To, čo je všeobecné, teda aj prenosné z látkového podložia vyvažuje v Uljanenkovej próze spôsob, akým uvádza, pôsobí a pointuje rozprávač svoju existenciu v gete Jihu a ako sa rozvíja jeho iniciatíva postupného obnažovania mechanizmu vzniku a vyvrcholenia nenávisti, pomsty a vraždy do precízne sústredenej štylistiky zobrazovania videného, počutého, precíteného. Narátor v pubescentnom veku má za sebou telesné a asociálne skúsenosti jednotlivca, ba je takmer na konci svojej prázdnej a nepotrebnej existencie, ale myslou naliehavo zachytáva osobný priestor, dôsledky odvíjané a porovnávané s podobenstvami a ludovou múdrostou, senzibilným záznamom svojich zmyslových očarení zo zmien prírodného sveta tak, že sa vo veku nenaplnených osemnástich rokov stáva až nedôveryhodnou postavou na tak vyformované osobnostné ustrojenie $\mathrm{z}$ rozsahu vedenia a estetiky výrazu, akoby mladícky narátor ostal dlžníkom pri objasnení pôvodu tolkých poznatkov zachytených v ním sformulovaných gnómach, početných a funkčných odkazoch na kultúrne dejiny. Napokon prekvapí jeho premyslené zvažovanie o príčine existencie a o zmysle života, ale aj o sebe v tom zvláštnom prostredí zvráteného juhu/Juhu: „Já jsem měl sportovni postavu, řeckej profil a chůzi jako boxer. Holkám se to libilo, to jsem moc dobře vědel. Věděl jsem, že jsem hezkej. Jen jsem netušil, co vlastněchci“ (s. 29). Narátor vie o svojom telesnom pôvabe, ale vie i o tom, že nedokáže preniknút do skupinky vodcov geta, má nemalé skúsenosti s drogami, ženami, prežíva emóciu, ktorú považuje za lásku a osobnú slabost voči dievčatu z dobrej rodiny, ale strategicky rešpektuje inštrukciu, ako v gete prežit, čím zhodnocuje svoju výhodu voči ostatným takto: „nikdy jsem se nesnažil předvídat" (s. 136). Princíp kontrastu udržuje kompozíciu textu v zovretom celku, ale koordinátorom toho, čo rozprávač vysunie do pozornosti čitatela, je kategória literárneho času. Próza má dva časy: prvý (objektívny) čas rámcuje vonkajší priestor látky opakovaným odvolávaním sa na rok 1979 a rozprávanie narátor („prcek“) končí sa odkazom na pár mesiacov a začne sa odpočítavat rok 1980; druhý (kompozičný) čas nerešpektuje chonológiu udalostí, ich následnost'. Stratégia textu sa sústreduje na kontrastné zobrazovanie toho, čím žijú mladí („smrkáči“) a vekom i skúsenostami s políciou zrelí asociáli. Napätie vzájomných vztahov a obludnost’ opísaných akcií či správania sa uvol’nuje osobným citovým zázemím: „Po konci, po milováni nebo po životě jde o něco jinýho. Neni to láska, ale něco mnohem víc. A já jsem to už věděl. Jen jsem se bál vyslovit to nahlas“ (s. 6364). Kompozičné posúvanie časti (ja) a celku (oni) v lokalite juh/Juh premyslene stupňuje napätie medzi mladistvými, mladými a zrelými, medzi chlapcami a dievčatami z rozvráteného sveta vztahov, morálky, praktík zaznamenaných v rozprávaní detailov a stupňovaným opakovaním priebehu vraždy, ktorá nič nezmení a rovnako nič nevyrieši, ale naplní emóciu vášnivej ženskej nenávisti a dokoná svoju pomstu. Detail sa vo výrazovej zdatnosti autora stal dominujúcim štylistickým a významovým nástrojom, jeho precíznost a nekonvenčnosṫ sa vzpierajú literárnemu vekové a typu, ktorým sa narátor „vymedzil“ sám: „Na nikoho jsem nemyslel ani nevzpominal [...] vole ty ses vymanil a prežils to [...] a pak začít od začátku, celý znova. [...] Víc nez dvacet let jsem po tom všem ani nevzdechnul“ (s. 136). Ak si treba postavu rozprávača čímsi osvojit, tak to budú nezvyčajne početné odkazy na osobnú mladost', ironizovanie, znevažovanie, reflektovanie, mudrovanie o nej a vyhranený postoj negácie všetkého a všetkých, čo nie sú napojení na to krátke obdobie života, ktoré sa označuje za detstvo, dozrievanie a spája sa s pár rokmi stratenej mladosti, do ktorej sa uloží všetko, čím sa, ked' to dokáže, presadzuje subjekt v dospelosti.

\section{Cestoval jsem po rozpadajících se územích, po vnitřních hranicích SSSR}

Román Sergeja Lebeděva ${ }^{4}$ Děti srpna svoju látku naviazal na rodinné rozprávanie o starom otcovi Michailovi, ktorý zahynul, ako sa v rodine traduje, vo vojne a na tajomný denník a záznam-

4 Sergej Lebeděv (1961), autor básní, esejí, filozoficko-sociologických textov a trilógie (podla Wikipedie): Hranice zapomněni (2012), Rok komety (bez vročenia), Déti srpna/ Srpnovi lidi (2016). 
ník starej matky Táne. Stará matka nesie vo svojom živote dve tajomstvá: prvým rešpektovaným a do fiktívneho príbehu vloženým tajomstvom je otec jej syna, muž Michail; druhým akceptovaným tajomstvom je jej práca v ochranných štátnych štruktúrach v súčasnosti už nejestvujúcej krajiny sovietov. Dostredivým miestom látky aj tematiky rozprávania vnuka v školskom a neskôr v dospelom veku je jeho emotívna istota: „I bez babiččina vysvětleni jsem pochopil, že ta kniha je moje, že je určená mně a že matce a otci bych se o ni možná zmiňovat neměl: babička své poselstvi uchystala jen a jen pro mě, protože je nepovažuje za schopné prerodu. Proto také pred nimi držela vše v tajnosti“ (s. 14). Už v prológu románu, po ktorom nasleduje v pohyblivých časových, meniacich sa priestorových a rozširujúcich sa personálnych blokoch pät odlišných, ale vo vzájomnom vztahu na problém nadväzujúcich (hladanie faktov, dokumentov, ludí a pravdy v minulosti) a negáciou poznania gradujúcich dejoch okolo protagonistu, utvoril rozprávač pevnú rámcujúcu schému naplnenú príbehmi o opakovaní sa vynaliezavých mocenských mechanizmov prekračujúcich z minulosti do prítomnosti, ktoré sa vkliesni do pamätí jeho rodiny a do dejín krajiny. Ilúzia o zmenách v osobnom živote sa znásobí poznaním o prežívaní starých, účinných a brutálnych praktík v prítomnom „slobodnom“ živote krajiny. Personalizovaním jednotlivých udalostí, v ktorých je rola rozprávača sekundárna (cestuje, hladá, hovorí s lud'mi, poznáva nepoznané praktiky moci) v tom, čo by bolo možné označit za relativizovanie gnómy, podla ktorej dva razy do tej istej rieky nemožno vstúpit, teda vo vztahu k literárnej skutočnosti stráca svoju poznávaciu hodnotu v polarite vztahov: najskôr babič$\mathrm{ka}$, vnuk a rodičia, potom babičkin pominuvší sa starý svet v krajine sovietov a vnukov nový svet v krajine bez sovietov. Stratégia kontrastu presúvaná paradoxne do novej, d’alšej, takmer nemennej kontinuity obsahov, ktoré plynúci čas nesie v politickom, spoločenskom systéme krajiny vytvorila rámec na stretanie, porovnávanie a bezmocné rešpektovanie dotykov starého systému riadenia krajiny aj života jeho občanov a jeho aktualizovaná, no takmer neinovovaná adaptácia vnesená bez zmien do nových spoločenských, územných, politických a hodnotových pravidiel vedenia krajiny opísané vo vertikále jej organizmu a mechanizmov na ochranu bezpečnosti štátu pred vonkajším, zvlášt vnútorným nepriatelom. Postupné spresňovanie faktami a objektívnou skutočnostou zdedených záznamov po starej matke má svoje príbehové, poznávacie a nazeracie opodstatnenie však iba vtedy, ked' sa začnú medzery v pamätiach napíňat ňou zámerne vynechanými detailmi, o čo sa zaslúži vnuk hladaním pravdy o svojom dedovi a túto svoju zručnost' i zálubu neskôr povýši na hladanie $\mathrm{v}$ archívoch, $\mathrm{v}$ teréne, medzi pamätníkmi na profesiu, poslanie i nezvyčajnú hru na poznanie osudov tých, ktorí sa v bývalej rozlohou, národmi a národnostami, politickými spojenectvami, ekonomickou, tieňovou ekonomickou mocou v rozsiahlej krajine (lágre, gulagy, vyhnanstvo, úmrtia, mafia) stratili bez stopy. Základná kompozičná forma pracuje s historickým časom, rok 1921, ale najmä s rokmi 1991 až 1994, priestorovo s rozsiahlym územím bývalého Sovietskeho zväzu, s verifikovatelnými reáliami (národné vojny na ázijskom území bývalého ZSSR po devätdesiatych rokoch, Jel'cin a priezviská ázijských vodcov nových vojnových konfliktov). $\mathrm{V}$ rodine vnuka s dávnou tradíciou vzdelancov a milovanou starou matkou Táňou sa v čase, ked' sa pominie, sa $\mathrm{k}$ jej pamätiam dostane jediný potomok rodu a začne hladat' $\mathrm{v}$ záznamoch nezachytené odpovede na nedopovedané príbehy, osudy a deje. V texte sa volne pracuje so žánrom rukou písaných záznamov, čo bude zámer, ktorý objasní príbehová línia zo životných osudov, práce a početné dramatické udalosti, ktoré postretnú vnuka na ceste za pravdou. Finále jeho úsilia nájst' tých, ktorí sa stratili, končí jeho vypočúvaním štátnou bezpečnostnou službou („muž - fotografia“), ktorej sa napokon upíśe do spolupráce, predtým však udá toho, kto mu doteraz pomáhal pri hladaním materiálov, kontaktov a odpovedí, lebo ho vystrašia možným osudom jeho priatel'ky a pre neho znevažujúcou informáciou: „Vás ale nepotrebujeme. My potřebujeme Faischanova“ (s. 243). Jedinečné, osobné až intímne v záznamoch starej matky sa mení 
na všeobecné v novej spoločenskej realite podporené vnukovým (pars pro toto) poznaním, že sa zmenil názov aj rozloha krajiny, zmenili sa jej vonkajšie hranice, ale mechanizmus moci a systém jej udržania funguje d’alej aj s tými istými článkami a profesijnými či ludskými spôsobilostami. Nápad utiecṫ z krajiny pred mocou orgánov nového štátu a uniknút pred jeho mocenským tlakom sa ukáže tak naivný, ako hra starej matky na (ne)vysvetlenie, prečo dedo Michail $\mathrm{v}$ rodine nikdy nebol, ožije len $\mathrm{v}$ ňou bez zmeny opakovanom príbehu.

\section{Život už je takový, že někdo je chvíli přítel, chvíli nepřítel}

Nové Rusko, ako ho označuje v próze Nejsem Rus Michail Ševeljov, ${ }^{5}$ žije v informačnom kolotoči médií, do ktorých neodmyslitel'ne patrí protagonista (žid, dieta intelektuálov, rešpektovaný publicista a novinár) Pavol Volodin pôsobiaci v denníku Moskovský martýr. Próza, prekladatel' ju označuje žánrovo za novelu, má exkluzívny (od reálií dištancujúci sa) názov Nejsem Rus, ale kým sa udalosti, ktoré kompozične ako nástroj príbehovej gradácie segmentuje chronológiu obchádzajúci čas s funkciou názvu pre jednotlivé príbehové sekvencie, nachádzajú uplatnenie ako situačné sentencie $\mathrm{s}$ iniciačnou funkciou. Tá sa uplatňuje vo výraze silou, emóciou, alúziou na tragické, groteskné, ale voči téme vždy aktuálne ako výzva: Život už je takový, že někdo je chvili prítel, chvili neprritel (s. 136); Chce se stát hrdinou Ruska? (s. 27); Židovské spiknuti proti moslimuim? (s. 29); Moskva, jak známo, neni město, je to skutečná Grimpenská bažina, pohlti tě i s hlavou, stačı jen vstoput. Pořád se něco děje... (s. 36). Nielen $\mathrm{v}$ Moskve, ale aj v novom Ruska „se pořád něco děje“, a to niečo vytvorilo strhujúci prehlad historických, politických, etnických a ludských postojov k tomu, čo priniesli zmeny. Dve literárne postavy: vyhladávaný novinár stredného veku,

5 Michail Ševeljov (1959), pôvodne text publikoval v roku 2015 v periodiku Zmanja pod názvom Sled udalostí (Posledovatelnost sobytij) a v roku 2016 ho vydáva knižne pod názvom Nejsem Rus.
Rus Pavol Volodin a mladík z okraja spoločnosti, Rus s dramatickou bezdomoveckou prítomnostou, Vadik Seregin, na svojom vztahu, ktorý overí dávnu skúsenost', že sa za dobro a pomoc kruto platí, stanú sa prototypmi tých občanov nového Ruska, ktorí „na vlastni kůži zažili všechny útrapy nedávnych mocenských výbojů „nového Ruska“ - prvni čečenskou válku v letech 1994 až 1996, druhou čečenskou válku, která začala v roce 1999 a skončila prakticky až po deseti letech, dodnes neobjasnené teroristické útoky na obytné domy v Moskvě a Volgodonsku [...], včetně současné krize a války na Ukrajině a anexe Krymu. Vadik se po tom, co ve své zemi prožil, odmitá pokládat se za Rusa: Já nejsem Rus. Byl jsem. Ale už nechci. Moje národnost je ted' - Nerus" (s. 171, 173). Próza Nejsem Rus beletrizovanou rekonštrukciou územnej a mocenskej (lokálnej) vojny aktualizuje politickú a ludskú katastrofu: na bývalej sovietskej zemi sa vraždia obyvatelia bývalého Sovietskeho zväzu. Autor pracuje s verifikovatel'nými reáliami: mená politických a vojenských činovníkov ${ }^{6}$, reálny geografický priestor a územné lokality ${ }^{7}$, organizačné reálie a nástroje štátnej $\operatorname{moc}^{8}$, konfliktné udalosti, pracuje s dátumom ${ }^{9}$, pripomína mediálne reálie ${ }^{10}$. Autor v role protagonistu pomenúva neruské etniká, zapojí termín terorista, svoju výpoved' o novom Rusku ukončí katastrofou, je ňou výbuch kostola plný dedinských rukojemníkov a smrtou Vadika. Toho bezdomovca Vadika, ktorý na počiatku rozprávania bol trpený asociála a ku koncu príbehu sa mení na odhodlaného muža s poslaním vymedzit aktuálny mravný imperatív: žiada v ultimáte, aby sa ruský

6 Černomyrdin, Jelcin, Gorbačov, Janukovyč, Putin, Basajev, Chabarov, Rojzman, Chodorkovskij, Jevtušenko a d’alší.

7 Moskva, Petrohrad, Čečensko, Ukrajiny, Krym, Majdan, Novomoskovsk, Nikolskoje, Čerkizvasky trh, Machačkala, Karamachi, Čabanmachi, Karabach, Južné Osetsko, Abcházko a mnohé d’alšie.

8 Jednotky rýchleho nasadenia OMON, oddiely rýchlej reakcie SOBR, Federálna bezpečnostná služba, KGB, uralský geng, verbovanie protagonistu do služieb KGB a iné.

9 Beslanská škola, Majdan, glasnost', JUKOS, lokálne vojny v ázijských krajinách bývalého ZSSR.

10 YouTube, Moskovský kuriér, TV Perspektíva, Zvesti. 
prezident verejne ospravedlnil za to: „... co dělaji na Ukrajině je hotové šilenství.. že když je Krym náš, tak proč ho krademe..., že nejde rozpoutat válku v Donbasu kvili retingu..., že to celé skonči katastrofou..." (s. 162-163). Prítomnost' či neprítomnost' postavy Vadika, indikátora pohybu v čase (1996, 2004-2014, 2015, Osmdesáta, devadesáta léta, 1999, zima a jaro, 1999, léto, 1984, 1995, Dejme tomu, Před šesti hodinami, Nultá léta - a plynúci čas zachytený v pohybe hodinových ručičiek bez odkazu na logiku následnosti narácie voči názvom jednotlivých častí textu, ktoré majú číselné alebo textové pomenovanie od 22:34 až po 12:49), voči priestoru a reči/ jazyku s príkazom na vykonanie vojenských akcií (ruština, ukrajinčina, čečenský jazyk) a zdôrazňovania napätia, s ním spojeného tlaku konfliktnej akcie na vystupňovanie katastrofickej situácie nie s podnetom na konečnú eskaláciu násilia, krutosti, ponižovania a zabíjania, ale s nečakaným mravne zdôvodneným rozhodnutím outsidera Vadika. Najskôr v texte jeho utltimáta: „Požadujeme, aby prezident Ruské federace vystoupil v televizi a omluvil se za dvě války - v Čečensku a na Ukrajině. Pak budou všichni rukojmi propuštěni. V opačném prípadě budou zabiti“ (s. 97) a po jeho odmietnutí pokojným kladením otázok nadčasovej platnosti, ktoré nehladajú vítazov. Naopak, vypravujú sa po objasnenie príčin a po odpovede na ne k tým, ktorí budú raz, ked' príde ten čas, zodpovednost' za zlo a ničenie aj tým, že dnes iba mlčia: „A žádná inteligence neexistuje, to jsou jen výmysly sovětských organizátoru života. Existuji intelektuálové, ale společenstvi intelektuáli - žel bohu. Protože kdyby existovalo, pak by se historie poslednich triceti let Ruska popisovala jinak"... (s. 116). Pointou sugestívne, ale predovšetkým formou dokumentárne modelovaného rozprávania vyhladávaného publicistu prináša Šaveljov osobnú, azda aj generačnú správu o zložitej a nejasnej prítomnosti ruskej spoločnosti a o odcudzení sa územných susedov z niekdajšieho spoločného štátu. $\mathrm{V}$ priesečníku minulosti a budúcnosti čaká na odpoved' autorova sentencia: „Ruský národ? Stejný jako všechny ostatni, jenom moc ustrašený, proto si s nim můžeš dělat, co chceš...". Nateraz sa s otázkou a odpoved'ou, ako porozumiet a vyrovnat sa s nedávnou minulostou a prijat nuansy novej skutočnosti spájajú v modernej ukrajinskej a ruskej histórii aj literatúre tak ich príbehové aktualizácie, ako historické spoločenské reinterpretácie, pritom umelecká próza anticipuje nateraz závažný mravný problém súčasníkov, na ktorý si vyžiadajú všestranne pripravenú odpoved' po generácii otcov aj ich potomkovia.

E-mail:viera.zemberova@ff.unipo.sk 